\title{
A test of the hybrid origin of Korean endemic Sedum latiovalifolium (Crassulaceae)
}

\author{
Young-Gi Yoo and Ki-Ryong Park ${ }^{1 *}$ \\ Department of Biology, Kyungnam University, Changwon 51767, Korea \\ ${ }^{1}$ Department of Urban Environmental Engineering, Kyungnam University, Changwon 51767, Korea \\ (Received 12 November 2016; Revised 15 December 2016; Accepted 21 December 2016)

\section{한국특산 태백기린초(돌나물과)의 교잡 기원에 대한 검증} \\ 유영기 · 박기룡 ${ }^{1 *}$ \\ 경남대학교 생물학과, ${ }^{1}$ 경남대학교 도시환경공학과
}

\begin{abstract}
Eighteen morphological characters from 40 populations and ten isozyme loci from 35 populations of Sedum latiovalifolium and related species were examined to investigate the degree of morphological and genetic variation. The high-frequency marker alleles MDH-2 ${ }^{\mathrm{a}}$ and PGI- $1^{\mathrm{a}}$ in S. aizoon, S. kamtschaticum, and $S$. zokuriense did not appear in the populations of S. latiovalifolium. In addition, the high-frequency allele (MDH$2^{\circ}$ ) in S. latiovalifolium appeared at a very low frequency in other subg. aizoon species. Thus, the isozyme data did not support a hybrid origin of S. latiovalifolium from S. aizoon with S. kamtschaticum. The results of an unweighted pair-group method using the arithmetic average method and a principal components analysis using morphological data also did not support a hybrid origin of S. latiovalifolium. However, our data strongly suggest that some individuals from the populations found in the Gumdaebong area were most likely hybrids due to introgression between S. latiovalifolium and S. kamtschaticum or S. aizoon and S. kamtschaticum.
\end{abstract}

Keywords: Sedum latiovalifolium, hybrid origin, Crassulaceae

적 요: 돌나물과 한국특산종 태백기린초의 교잡 기원에 대한 가설을 검증하고, 연관 종들의 형태적, 유전적 변이를 알아보기 위해 40 개 집단으로부터 18 개의 형태형질과 35 개 집단에 10 개 동위효소 좌위를 분석하였다. 동위효소 연구결과 가는기린초, 기린초 그리고 속리기린초에 높은 빈도로 나타났던 MDH-2a ${ }^{\mathrm{a}}$ PGI-1는 태백 기린초 집단에서는 전혀 나타나지 않았으며, 태백기린초의 모든 집단에서 높은 빈도로 나타나는 $\mathrm{MDH}-2^{\mathrm{c}}$ 는 다른 가는기린초아속 식물에서는 낮은 빈도로 나타나고 있어 태백기린초가 기린초와 가는기린초의 잡종화를 통해 기원되었다는 기존의 가설을 지지할 수 없다. 그러나 금대봉 일대의 일부 집단의 개체들은 태백기린초 와 기린초 혹은 기린초와 가는기린초 사이에서 형질이입에 의해 만들어진 교잡 개체일 가능성이 높은 것으 로 생각된다.

주요어: 태백기린초, 교잡 기원, 돌나물과

교잡(hybridization)은 식물의 일반적 종분화 현상으로 육상식물의 진화에 중요한 역할을 해왔으며(Arnold and
Hodges, 1995; Ellstrand et al., 1996), 이를 규명하기 위한 전통적인 연구들은 주로 형태형질과 세포학적 증거에 기

\footnotetext{
*Author for correspondence: park@kyungnam.ac.kr
} 
초하여 이루어져 왔다. 이와 같은 연구들은 형태적으로 중간 형질을 갖고 있다는 사실만 나타낼 뿐 명확히 교잡 기원을 규명하는 데는 한계가 있기 때문에, 최근 들어 정 확히 교잡 기원을 밝히기 위해서 분자적 표식(molecular marker)을 이용한 연구가 주로 이루어지고 있다 (Rieseberg et al., 1990; Morrell and Rieseberg, 1998). 특히, 분자적 자료는 (1) 분석에 유효한 독립적인 표식자가 많 고, (2) 대부분의 변이가 유전되며, (3) 많은 분자적 표식 자들은 형태형질에 비해 자연선택에 영향을 덜 받는 것 으로 알려져 있다(Rieseberg et al., 1993; Rieseberg and Wendel, 1993). 특히, 분자적 증거로서 동위효소가 전통적 으로 유용하게 사용되어 왔다(Gallez and Gottlieb, 1982; Crawford, 1989).

돌나물과(Crassulaceae) Sedum L. 내의 subgen. Aizoon Koch ex Schönland 식물은 주로 동아시아에 약 7종이 분포 하고, 분류학적으로 논란이 많은 분류군으로 알려지고 있 으며(Amano, 1990), 이 중 국내에는 학자에 따라 3-7종이 서식하는 것으로 보고하고 있다(Nakai, 1909; Chung, 1957; Park, 1974; Chung and Kim, 1989; Lee, 1996).

Lee (1992)는 크기가 약 $20 \mathrm{~cm}$, 잎은 호생 또는 대생하고 줄기 끝에 넓은 난형으로 상면이 오목한 형태를 가지며, 금대봉 일대에 서식하는 것을 태백기린초(Sedum latiovalifolium Y. N. Lee)로 신고유종으로 기재하였다. 이후, Lee (2000)는 태백기린초를 금대기린초라 칭하고, 형태형질 에 기초하여 가는기린초 $(S$. aizoon L.)와 기린초 $(S . k a m t s c-$ hatium Fisch. \& Meyer)나 가는기린초와 넓은잎기린초 $(S$. ellacombianum Praeger)의 교잡종이라는 가설을 제시했다. 교잡종은 이들의 부모종과 동일한 지역에서 서식할 가능 성이 높다는 연구결과(Morrell and Rieseberg, 1998)로 미루 어 볼 때, 태백기린초가 서식하고 있는 지역에서 기린초 와 가는기린초가 함께 발견되는 점 등으로 보아 이들 종 간의 교잡을 통해 태백기린초가 기원되었을 가능성이 설 득력이 있어보인다. 최근 세포학적 연구에 의하면 가는기 린초 아속의 종들은 집단 내 염색체 수의 변이가 심하여 서로 다른 배체 간에 교잡이 이루어졌을 가능성이 크다고 하겠다(Uhl and Moran, 1972; Amano, 1990; Amano and Ohba, 1992).

본 연구에서는 형태형질을 이용한 수리분석과 동위효 소 분석을 토대로 한국 특산 태백기린초의 교잡 기원에 대한 가설을 검증해 보고자 하였다.

\section{재료 및 방법}

\section{재료}

태백기린초의 교잡 기원에 관한 가설을 검증하고, 태백 기린초와 연관 종들의 유전적 변이와 분화 정도를 알아보 기 위해 강원도 금대봉, 정동진, 충북 제천, 단양, 소백산, 태백산, 거제 해금강, 천마산, 주왕산, 속리산, 울릉도, 가

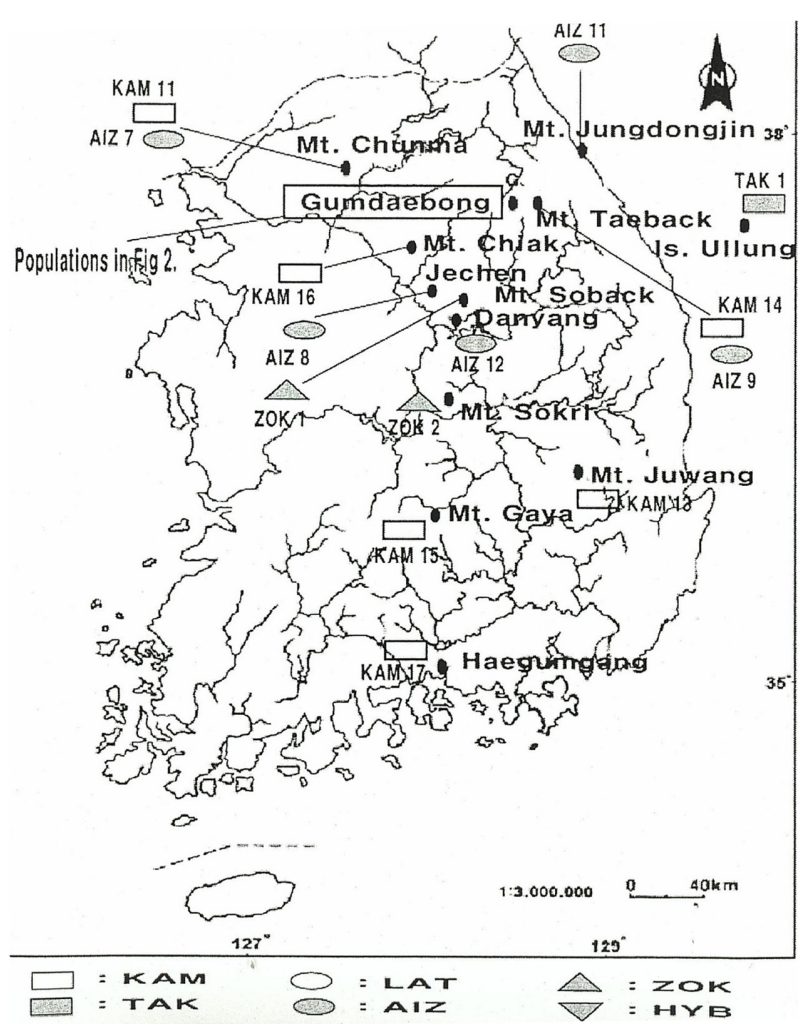

Fig. 1. Geographic distribution of Sedum latiovalifolium and related species. AIZ, S. aizoon; HYB, hybrid population; KAM, $S$. kamtschaticum; LAT, S. latiovalifolium; TAK, S. takesimense; ZOK, S. zokuriense.

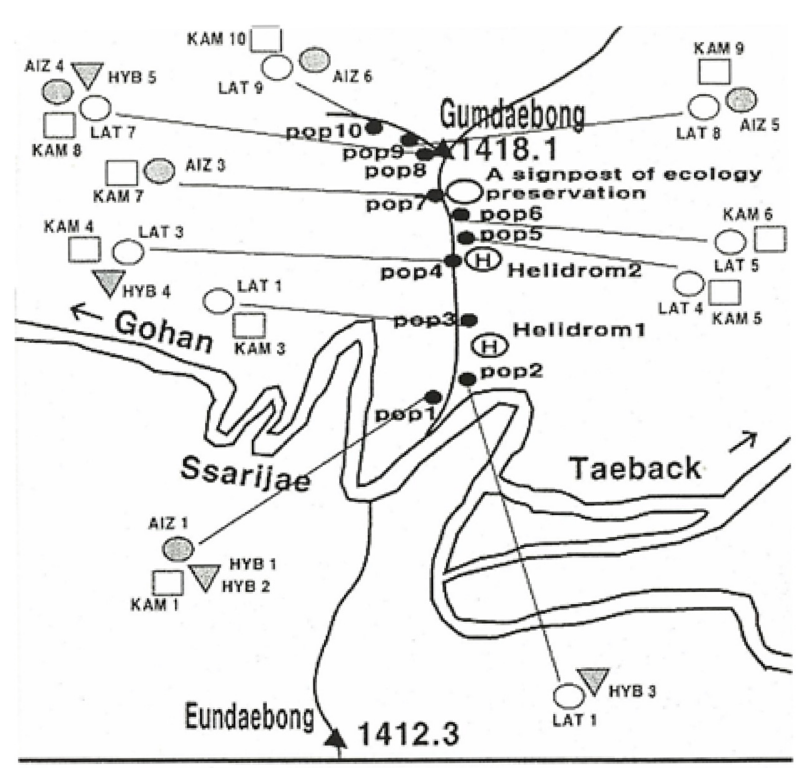

$\bigcirc:$ LAT $\bigcirc:$ AIZ $\square$ : KAM $\nabla:$ HYB

Fig. 2. Distribution near the Gumdaebong areas of Sedum latiovalifolium and related species. AIZ, S. aizoon; HYB, hybrid population; KAM, S. kamtschaticum; LAT, S. latiovalifolium; TAK, S. takesimense; ZOK, S. zokuriense. 
Table 1. Collection data for Sedum latiovalifolium and related species using numerical and isozyme analyses.

\begin{tabular}{|c|c|c|c|}
\hline Scientific name & Population & Locality & $\begin{array}{c}\text { Specimen } \\
\text { Number }\end{array}$ \\
\hline \multirow{9}{*}{$\begin{array}{l}\text { S. latiovalifolium } \\
\text { (LAT) }\end{array}$} & LAT 1 & The first helidrom at Gumdaebong & YOO-01 \\
\hline & LAT 2 & $100 \mathrm{~m}$ from the first helidrom at Gumdaebong & YOO-02 \\
\hline & LAT 3 & The second helidrom at Gumdaebong & YOO-03 \\
\hline & LAT 4 & $100 \mathrm{~m}$ from the second helidrom at Gumdaebong & YOO-04 \\
\hline & LAT 5 & $100 \mathrm{~m}$ before the signpost of ecology preservation & YOO-05 \\
\hline & LAT 6 & The signpost of ecology preservation & YOO-06 \\
\hline & LAT 7 & Between the signpost of ecology preservation and Gumdaebong & YOO-07 \\
\hline & LAT 8 & 50 m east of Gumdaebong & YOO-08 \\
\hline & LAT 9 & $100 \mathrm{~m}$ east of Gumdaebong & YOO-09 \\
\hline \multirow{12}{*}{$\begin{array}{l}\text { S. aizoon } \\
\text { (AIZ) }\end{array}$} & AIZ 1 & $100 \mathrm{~m}$ from the entrance of Gumdaebong & YOO-10 \\
\hline & AIZ 2 & $100 \mathrm{~m}$ from the second helidrom at Gumdaebong & YOO-11 \\
\hline & AIZ 3 & The signpost of ecology preservation & YOO-12 \\
\hline & AIZ 4 & Between the signpost of ecology preservation and Gumdaebong & YOO-13 \\
\hline & AIZ 5 & $50 \mathrm{~m}$ East of Gumdaebong & YOO-14 \\
\hline & AIZ 6 & $100 \mathrm{~m}$ East of Gumdaebong & YOO-15 \\
\hline & AIZ 7 & Mt. Chunma & YOO-16 \\
\hline & AIZ 8 & Jeacheon & YOO-17 \\
\hline & AIZ 9 & Mt. Taeback & YOO-18 \\
\hline & AIZ 10 & Gumdaebong & YOO-19 \\
\hline & AIZ 11 & Jungdongjin & YOO-20 \\
\hline & AIZ 12 & Danyang & YOO-21 \\
\hline \multirow{17}{*}{$\begin{array}{l}\text { S. kamtschaticum } \\
\text { (KAM) }\end{array}$} & KAM 1 & $100 \mathrm{~m}$ from the entrance of Gumdaebong & YOO-22 \\
\hline & KAM 2 & The first helidrom at Gumdaebong & YOO-23 \\
\hline & KAM 3 & $100 \mathrm{~m}$ from the first helidrom at Gumdaebong & YOO-24 \\
\hline & KAM 4 & The second helidrom at Gumdaebong & YOO-25 \\
\hline & KAM 5 & $100 \mathrm{~m}$ from the second helidrom at Gumdaebong & YOO-26 \\
\hline & KAM 6 & $100 \mathrm{~m}$ before the signpost of ecology preservation & YOO-27 \\
\hline & KAM 7 & Signpost of ecology preservation & YOO-28 \\
\hline & KAM 8 & Between the signpost of ecology preservation and Gumdaebong & YOO-29 \\
\hline & KAM 9 & $50 \mathrm{~m}$ East of Gumdaebong & YOO-30 \\
\hline & KAM 10 & $100 \mathrm{~m}$ East of Gumdaebong & YOO-31 \\
\hline & KAM 11 & Mt. Chunma & YOO-32 \\
\hline & KAM 12 & Gumdaebong & YOO-33 \\
\hline & KAM 13 & Mt. Juwang & YOO-34 \\
\hline & KAM 14 & Mt. Taeback & YOO-35 \\
\hline & KAM 15 & Mt. Gaya & YOO-36 \\
\hline & KAM 16 & Mt. Chiak & YOO-37 \\
\hline & KAM 17 & Haegeumgang & YOO-38 \\
\hline
\end{tabular}


Table 1. Continued.

\begin{tabular}{|c|c|c|c|}
\hline Scientific name & Population & Locality & $\begin{array}{c}\text { Specimen } \\
\text { Number }\end{array}$ \\
\hline \multirow{2}{*}{$\begin{array}{l}\text { S. zokuriense } \\
\text { (ZOK) }\end{array}$} & ZOK 1 & Mt. Soback & YOO-39 \\
\hline & ZOK 2 & Mt. Sokri & YOO-40 \\
\hline $\begin{array}{l}\text { S. takesimense } \\
\text { (TAK) }\end{array}$ & TAK 1 & Is. Ullung & YOO-41 \\
\hline $\begin{array}{l}\text { S. middendorffianum } \\
\text { (MID) }\end{array}$ & MID 1 & Gichungsan botanic garden & YOO-42 \\
\hline \multirow{5}{*}{$\begin{array}{l}\text { Hybrid Population } \\
\text { (HYB) }\end{array}$} & HYB 1 & $100 \mathrm{~m}$ from the entrance of Gumdaebong & YOO-43 \\
\hline & HYB 2 & $100 \mathrm{~m}$ from the entrance of Gumdaebong & YOO-44 \\
\hline & HYB 3 & The first helidrom at Gumdaebong & YOO-45 \\
\hline & HYB 4 & The second helidrom at Gumdaebong & YOO-46 \\
\hline & HYB 5 & Between the signpost of ecology preservation and Gumdaebong & YOO-47 \\
\hline
\end{tabular}

Abbreviation for species is given in parentheses.

야산 등지에서 태백기린초 9 개 집단, 가는기린초 12 개 집 단, 기린초 17 개 집단, 속리기린초 2 개 집단, 섬기린초 1 개 집단, 애기기린초 1 개 집단을 채집하여 실험에 사용하였 다. 또한, 기린초에 비해 줄기가 붉으며 잎의 형태가 넓어 태백기린초와 기린초의 교잡 집단으로 추정되는 2 개 집 단, 일반적인 가는기린초에 비해 키가 작으며 잎의 형태 가 가는기린초에 비해 넓어 가는기린초와 태백기린초의 교잡 집단으로 추정되는 2 개 집단, 줄기의 하부는 가는기 린초의 잎의 형질을 가지고 있고 상부는 기린초의 형질을 가지고 있어 가는기린초와 기린초의 교잡 집단으로 추정 되는 1 개 집단 등 총 47 개 집단을 채집하였다(Figs. 1,2 , Table 1). 특히 강원도 금대봉에서는 지리적으로 교잡 여 부를 정밀하게 알아보기 위해 10 개 집단으로 세분하여 채 집하였다. 각 집단으로부터 형태 형질의 수리 분석을 위 해 석엽표본으로 만들어 사용하였으며, 사용된 표본은 경 남대학교 표본관(KNUH)에 보관하였다. 동위효소 분석을 위해 각 집단에서 10 개체 이상으로 어린잎을 채취하여 효 소원으로 이용하였다.

\section{형태형질분석(morphological character analysis)}

한국산 돌나물과 가는기린초아속 내의 형태 형질 분석 을 위해 총 40 개 집단에서 40 개체를 이용하였다(Table 1). 이를 실험재료로부터 18 개의 형태형질을 선정하여 측정 하였으며(Table 2), 측정된 형태형질로 data matrix를 작성 하여 NTSYS Program (Rohlf, 1992)을 이용하여 유집분석 (cluster analysis)을 실시하였다. 본 분석을 위해 측정된 형 질들을 표준화하였으며, 표준화한 값을 기초로 각 operational taxonomic unit (OTU) 간의 분류거리(taxonomic distance)를 계산하여 비가중-산술법(unweighted pairgroup method using arithmatic average, UPGMA)을 이용하 여 전형질도를 그렸다. 또한 집단 간의 총체적인 유집 경 향을 분석하기 위한 주성분 분석(principal components
Table 2. Morphological characters from Sedum latiovalifolium and related species for numerical analysis.

\begin{tabular}{l}
\hline \hline No. \\
\hline 1. Length of the third leaf from top of the stem (LTL) \\
2. Length/width of the third leaf from the top of the stem (LWL) \\
3. The longest internode length (LIL) \\
4. The shortest internode length (SIL) \\
5. Length of stem (LS) \\
6. Stem length/diameter at base (LD) \\
7. Number of serration of leaf (NS) \\
8. Angle of the nearest serration (AS) \\
9. Height of serration (HS) \\
10. Width of serration (WS) \\
11. Ovary length (OL) \\
12. Ovary length/width (OLW) \\
13. Petal length (PL) \\
14. Petal length/width (PLW) \\
15. Sepal length (SL) \\
16. Sepal width (SW) \\
17. Style length (STL) \\
18. Stigma length (SGL)
\end{tabular}

analysis, PCA)을 실시하였으며, 이를 위해 형질격자를 표 준화하고 상관계수(correlation coefficient)를 측정하였다. 이를 기초로 전체 형질 변이를 최대한 반영할 수 있는 3 개의 주요인 축을 추출하고 이에 대한 각각의 형질의 eigenvector 값을 계산했다(Table 3). 마지막으로 3개의 축 에 대해 각 OTU를 투영하여 이들의 총체적 유집경향을 분석하였다. 
Table 3. Eigenvectors and eigenvalues for the first three principal components from analysis of 18 characters of 40 populations of Sedum latiovalifolium and related species.

\begin{tabular}{llccc}
\hline \hline No. & \multicolumn{1}{c}{ Character (abbreviation) } & PC1 & PC2 & PC3 \\
\hline 1. & $\begin{array}{l}\text { Length of the third leaf from top of } \\
\text { the stem (LTL) }\end{array}$ & 0.275 & -0.769 & -0.084 \\
2. & $\begin{array}{l}\text { Length/width of the third leaf from } \\
\text { the top of the stem (LWL) }\end{array}$ & 0.422 & -0.564 & -0.229 \\
3. & The longest internode length (LIL) & 0.006 & -0.549 & 0.563 \\
4. $\quad$ The shortest internode length (SIL) & 0.195 & -0.521 & 0.519 \\
5. & Length of stem (LS) & 0.147 & -0.690 & -0.306 \\
6. Stem length/diameter at base (LD) & -0.240 & -0.422 & -0.108 \\
7. Number of serration of leaf (NS) & 0.287 & -0.285 & 0.560 \\
8. Angle of the nearest serration (AS) & 0.048 & -0.306 & -0.270 \\
9. Height of serration (HS) & 0.101 & 0.356 & 0.226 \\
10. Width of serration (WS) & -0.226 & -0.582 & -0.341 \\
11. & Ovary length (OL) & -0.807 & 0.072 & -0.097 \\
12. Ovary length/width (OLW) & -0.456 & 0.245 & -0.168 \\
13. Petal length (PL) & -0.901 & -0.147 & 0.198 \\
14. Petal length/width (PLW) & -0.489 & -0.210 & 0.383 \\
15. Sepal length (SL) & -0.781 & -0.142 & -0.129 \\
16. Sepal width (SW) & -0.784 & -0.230 & -0.217 \\
17. Style length (STL) & -0.861 & -0.142 & 0.328 \\
18. Stigma length (SGL) & -0.024 & -0.163 & -0.389 \\
& $\quad$ Eigenvalues & 4.395 & 3.028 & 1.852 \\
\hline
\end{tabular}

\section{동위효소 분석(isozyme analysis)}

가는기린초아속 35 개 집단에 대한 전분 전기영동(starch gel electrophoresis)을 실시하기 위해 채집한 식물의 어린잎 을 완충용액(Gottlieb, 1981)으로 막자사발에서 간 후, $1.5 \mathrm{~mL}$ tube에 담아 $-70^{\circ} \mathrm{C}$ 에 냉동시켜두었다가 전기영동 시에 해동한 다음 원심분리기를 이용하여 $6,000 \mathrm{rpm}$ 에서 1 분간 원심 분리하여 상충액을 paper wick에 흡수시켜 전 기영동에 사용하였다. Soltis et al. (1983)에 의한 방법을 양 간 변형한 $11 \%$ starch gel을 이용하여 2 개의 buffer systems 로 전기영동을 실시하였다. System I은 $0.0065 \mathrm{M} \mathrm{L}-$ histidine에 $0.007 \mathrm{M}$ citric acid monohydrate을 가지고 $\mathrm{pH} 6.5$ 로 적정한 electrode buffer, 증류수와 electrode buffer를 3:1 로 희석한 gel buffer를 이용하여 $30 \mathrm{~mA}$ 에서 30-40분 동안 전기영동한 후에 wick을 제거한 다음, $35 \mathrm{~mA}$ 에서 4-5시간 전기영동을 실시하였다. System II은 0.18M Tris, $0.004 \mathrm{M}$ EDTA에 $0.10 \mathrm{M}$ boric acid를 가지고 $\mathrm{pH}$ 8.6으로 적정한 electrode beffer, 증류수와 electrode beffer를 3:1로 희석한 gel buffer를 이용하여 $30 \mathrm{~mA}$ 에서 30-40분동안 전기영동
한 후에 wick을 제거한 다음 $35 \mathrm{~mA}$ 에서 4-5시간 전기영동 하였다. System I는 aldolase (ALD), 6-phosphogluconate dehydrogenase (6PGD), malate dehydrogenase (MDH), System II는 phosphoglucomutase (PGM), phosphoglucose isomerase (PGI), malic enzyme (ME), triosephosphate isomerase (TPI)를 분리하는 데 사용하였다. 젤로부터 유전 자형의 수를 계산할 때 고정이형접합자의 경우 이배체의 이형접합자와 동일하게 계산하였는데 이 경우 특히 빈번 하게 유전자의 중복현상이 나타나는 $\mathrm{MDH}$ 의 경우 이 중 복좌위를 하나의 좌위로 읽느냐 아니면 복수의 좌위로 읽 느냐에 따라 대립인자의 빈도 및 이형접합자 개체의 수에 는 차이가 생길 수 있고 이로 인해 자료 분석에 오류가 있 을 수 있다. 동위효소 자료로부터 BIOSYS-1 program (Swofford and Selander, 1981)을 이용하여 집단의 대립유전 자 빈도(allele frequencies), 각 좌위에 대한 대립유전자의 평균수(mean number of alleles per locus; $A$ ), 다형질 좌위의 백분율(percentage of polymorphic loci; $P$ ), 평균 측정 이형 접합자(mean observed heterozygosity; $H_{o}$ ), 평균 기대 이형 접합자(mean expected heterozygosity; $H_{e}$ )를 구하고, HardyWeinberg equilibrium 하에서 기대되는 이형접합자율에 대 한 편차인 Wright(1978)의 fixation indices (F-statistics)를 $F_{\mathrm{IS}}$, $F_{\mathrm{IT}}, F_{\mathrm{ST}}$ 의 세 요소로 나누어 구하여 유전적 변이와 분화를 측정하였다. 또한 Nei (1972)의 유전적 동질성(genetic identity)을 구하여 UPGMA 전형질도를 작성하였다.

\section{결 과}

\section{형태 형질 분석}

태백기린초와 연관 종 40 개 집단에 대해 18 개의 형질을 이용하여 유집분석을 실시하였다. 결과로 나타난 전형질 도(Fig. 3)에 의하면 태백기린초 9개 집단(LAT1-9), 가는기 린초 2 개 집단(AIZ8,10)과 기린초 1 개 집단(KAM12)은 하 나의 유집을 형성하였고, 기린초 9개(KAM2-5, 8-11, 14) 집 단들 또한 하나의 유집을 형성하고 있지만, 기린초 (KAM1, 13, 6) 집단들은 따로 떨어져서 가는기린초 집단 (AIZ2-6)과 유집을 형성하였다. 채집 당시 가는기린초와 태백기린초의 교잡 집단으로 여겨졌던 HYB1 집단은 가 는기린초와 유사한 형태형질을 많이 포함하고 있는 것으 로 밝혀졌으며, 식물체의 하부는 가는 기린초의 형태를 가지고 상부(잎과 꽃형질)는 태백기린초의 형태형질을 가지고 있는 HYB5 집단은 기린초집단과 유집되었다. 가 는기린초 집단들 중 천마산(AIZ7), 정동진(AIZ11), 태백산 (AIZ9)집단은 금대봉 일대에서 채집한 집단들(AIZ2, 3, 5, 6)과는 떨어져서 유집을 형성하였다. 섬기린초(TAK1)와 애기기린초(MID1) 집단이 가깝게 묶이면서 기린초 (KAM7) 집단과 유집을 형성하였으며, 속리기린초(ZOK2) 는 독립된 유집을 형성하였다. 하지만 일반적인 기린초에 비해 잎의 형태가 넓고 거치가 둥글며 상면이 오목하고 잎 


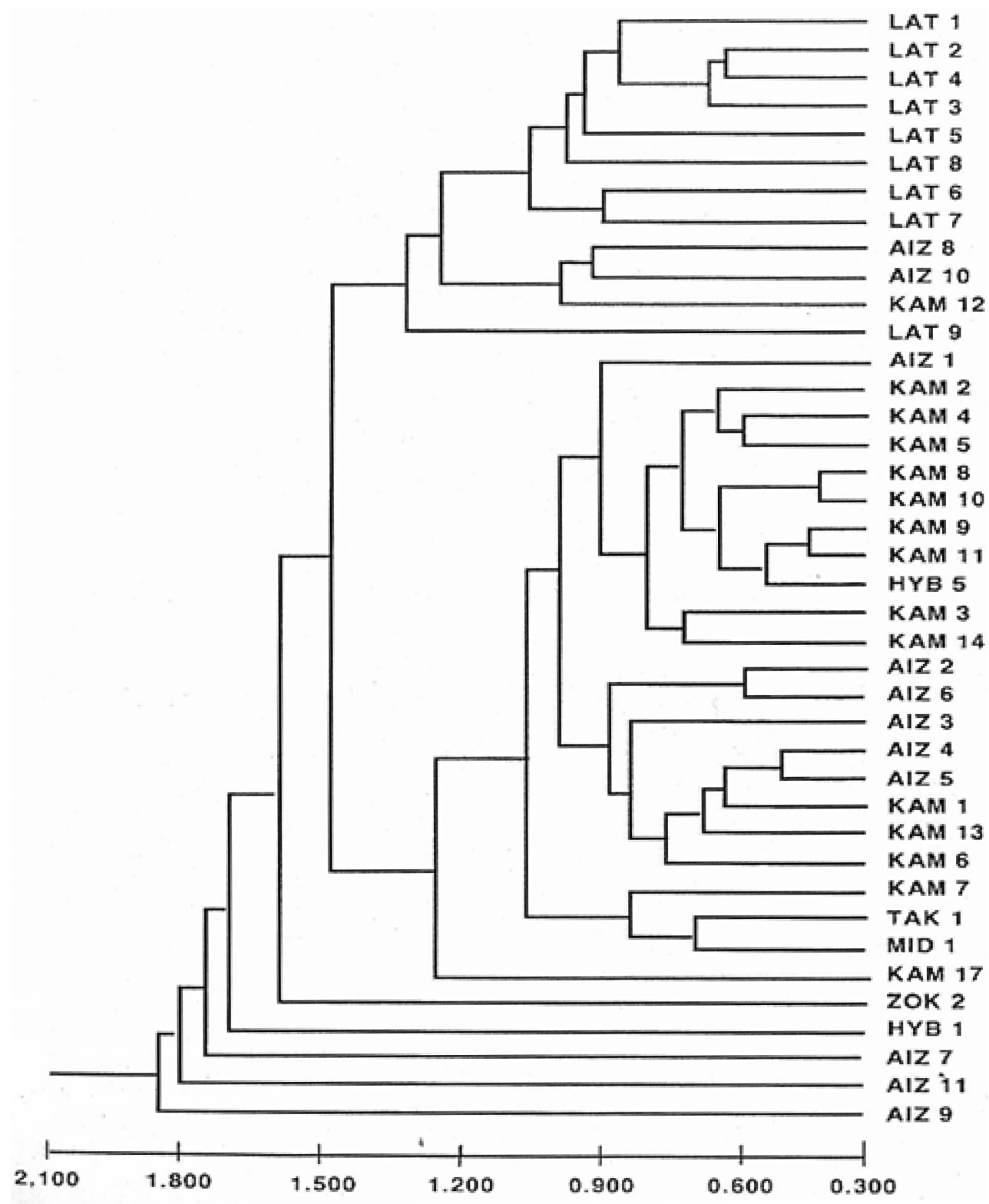

Fig. 3. Unweighted pair-group method using arithmetic average phenogram based on average taxonomic distance coefficients using 18 morphological characters from 40 populations of Sedum latiovalifolium and related species. AIZ, S. aizoon; HYB, hybrid population; KAM, S. kamtschaticum; LAT, S. latiovalifolium; TAK, S. takesimense; ZOK, S. zokuriense.

의 절간의 간격이 좁은 기린초(KAM17)는 다른 기린초 집 단들과 떨어져 유집을 형성하였다.

18 개의 동일한 형태형질을 기초로 주성분 분석(PCA)을 실시하였다. 먼저 전체 변이 $51.52 \%$ 를 나타내는 주요인축 (principal component axis) 3 개를 선별하였고(Table 3), 이 주 요인축으로 구성된 삼차원적 공간에서 투영한 OTUs(운 영분류단위)들의 분포를 보면, 태백기린초 집단은 하나의 독립된 군으로 분리되며 섬기린초, 속리기린초, 애기기린 초는 기린초와 가는기린초군으로 독립적인 공간에 분포 하였다. 기린초 집단과 가는기린초 집단의 일부 집단들은
각각의 군으로 형성되지만 일부의 집단들은 매우 가까운 공간에 서로 위치하는 것으로 나타났다(Fig. 4).

\section{동위효소분석}

35 개 집단에 대해 7 개 유전 좌위의 대립유전자빈도를 구하였다. 형태형질의 분석에 이용하였던 태백기린초의 $\mathrm{LAT} 4, \mathrm{LAT} 8$, 가는기린초 3 집단(AIZ1, 11, 13), 기린초 4 집 단(KAM3, 7, 10, 13), 교잡 집단으로 추정되는 HYB1은 효 소의 활성이 낮아 본 연구의 결과에서 제외시켰다. TPI-1, 6PGD-1, 6PGD-2의 유전좌위는 일부 개체에서 젤의 해상 


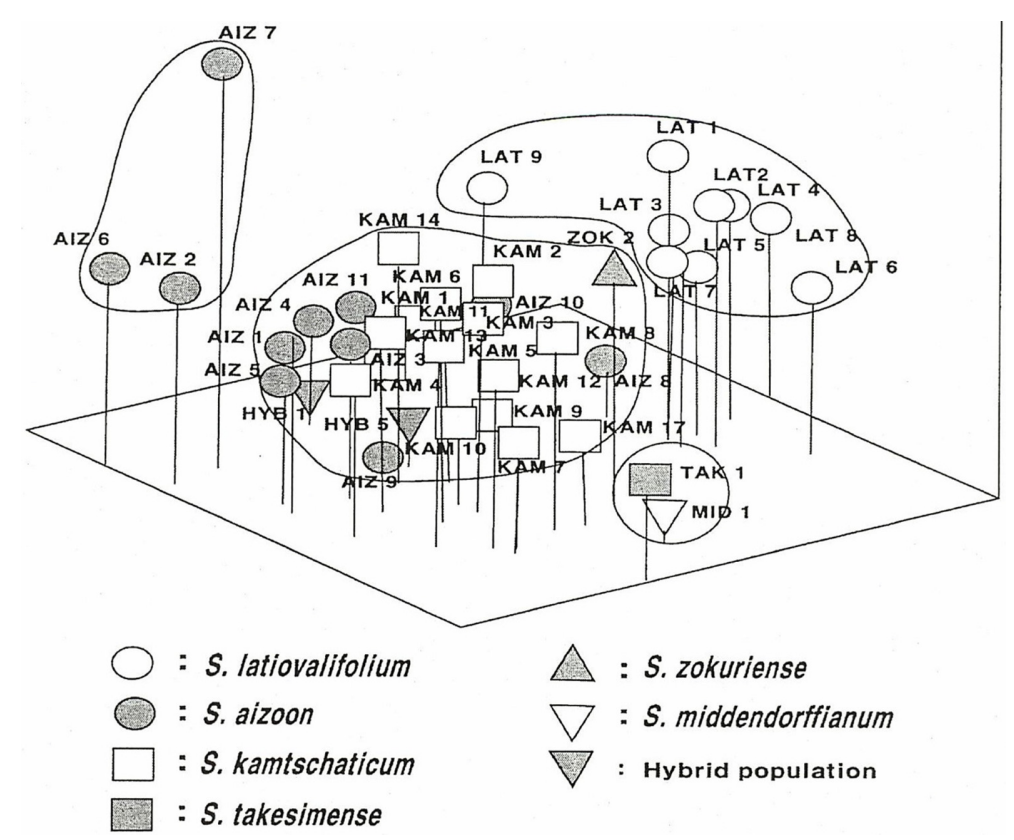

Fig. 4. Three-dimensional model of numbered populations derived from principal components analysis of 18 morphological characters of Sedum latiovalifolium and related species. AIZ, S. aizoon; HYB, hybrid population; KAM, S. kamtschaticum; LAT, S. latiovalifolium; TAK, S. takesimense; ZOK, S. zokuriense.

도가 떨어져 분석에서 제외시켜 총 5 개의 효소로부터 7 개 의 유전좌위에 대한 대립인자의 빈도를 분석하였다.

모든 개체에 있어 $\mathrm{MDH}-2^{\mathrm{b}}, \mathrm{PCM}-1^{\mathrm{b}}, \mathrm{ME}-1^{\mathrm{b}}, \mathrm{ALD}-1^{\mathrm{b}}$ 좌위 에서 높은 빈도의 대립인자를 보여 주었다. 태백기린초 개체들은 다른 가는기린초아속 종들과는 달리 $\mathrm{MDH}-2^{\mathrm{a}}$, PGM- $1^{\mathrm{c}}, \mathrm{PGI}-1^{\mathrm{c}}$ 대립인자가 전혀 나타나지 않았고, $\mathrm{MDH}-$ $2^{\mathrm{c}}$ 대립인자에서는 매우 높은 빈도를 나타내었다(Table 4). 태백기린초에서 거의 고정되어 나타나는 $\mathrm{MDH}-2^{2}$ 는 가는 기린초 집단에서 2 개 집단 만이 나타났고, 나머지 집단에 서는 전혀 나타나지 않았다. 각 분류군에 대한 유전적 변 이는 Table 5 에 나타냈으며, 좌위당 대립인자의 평균수 $(A)$ 는 속리기린초는 2.1 (1.7-2.4)로 가장 많았고, 태백기린초, 가는기린초, 기린초, 섬기린초는 1.6 으로 비슷한 수치를 나타냈다. 다형질 좌위의 백분율 $(P)$ 에서도 속리기린초가 78.6\% (57.1-100)로 가장 높았고, 그 다음으로 섬기린초, 태백기린초, 가는기린초, 기린초 순으로 나타났다. 교잡 기원으로 추정되는 집단들은 $57.1 \%, 57.1 \%, 28.6 \%, 42.9 \%$ 를 각각 나타내었으며 관찰된 이형접합자의 비율 $\left(H_{o}\right)$ 은 섬기린초는 0.571 로 가장 높았고, 다음으로 가는기린초, 태백기린초, 속리기린초, 기린초 순으로 나타났다. 교잡 집단으로 추정되는 집단들은 $0.571,0.571,0.286,0.429$ 를 각각 나타내었다. 그리고 이형접합자의 평균기대치 $\left(H_{e}\right)$ 는 태백기린초가 $0.260(0.079-0.346)$ 이고, 교잡으로 추정 되는 집단들은 $0.368,0.387,0.190,0.306$ 을 각각 나타내었 다. $\mathrm{MDH}-2$ 의 이형접합자를 하나의 좌위의 고정이형접합 자로 해석치 않고, 서로 다른 복수의 좌위가 함께 나타난
동형접합자로 본다면 이형접합자의 빈도는 본 연구결과 에서 측정한 수치보다 낮아질 수 있다. 즉, 이배체와 비교 할 때 다배체 종에서의 정확한 유전자빈도의 계산에는 한 계가 있을 수 있다.

Wright (1978)의 고정계수에 있어 태백기린초와 가는기 린초는 $F_{\mathrm{IS}}$ 의 평균수치가 음의 값을 보여주었고, 기린초와 속리기린초는 $F_{\mathrm{IS}}$ 의 평균수치가 양의 값을 가지고 있어 이 형접합자의 결여현상이 나타났다(Table 6). 집단간 유전 적 분화의 정도를 나타내는 $F_{\mathrm{ST}}$ 수치 역시 태백기린초와 속리기린초는 0.146 과 0.103 으로 낮은 수치를 보여주어 비교적 집단간 유전적 분화가 심하지 않는 것으로 나타 났다. 가는기린초와 기린초는 $0.492,0.544$ 로 상대적으로 높은 수치를 보여주어 집단간 분화가 심한 것으로 나타났 다.

유전적 동일성은 태백기린초 9 개 집단에서 0.952 로 제 일 높았고, 속리기린초, 가는기린초, 기린초 집단 순으로 태백기린초와 속리기린초 종 내에 매우 높은 유전적 동일 성을 보여준 반면 가는기린초와 기린초 집단은 낮은 수치 를 보여주었다. 또한 태백기린초와 HYB2, HYB3 집단 사이 에도 매우 높은 유전성 동일성 $(0.909,0.921)$ 를 보여주었다.

Nei의 유전적 동일성에 기초한 UPGMA phenogram을 보 면 형태 형질을 이용한 UPGMA phenogram과 동일하게 태 백기린초, 속리기린초, 섬기린초들은 각각 독립된 유집을 형성하고 있고, 가는기린초, 기린초들은 유집을 형성하지 못하고 서로 섞이어 나타났다. 기린초와 태백기린초의 교 잡 집단으로 추정되는 $\mathrm{HYB} 2, \mathrm{HYB} 3$ 집단은 태백기린초와 
Table 4. Allele frequencies of 7 polymorphic loci of 35 populations of Sedum latiovalifolium and related species.

\begin{tabular}{|c|c|c|c|c|c|c|c|c|c|c|c|c|c|c|c|c|}
\hline \multirow{2}{*}{ Locus } & \multicolumn{7}{|c|}{ LAT } & \multicolumn{9}{|c|}{ AIZ } \\
\hline & 1 & 2 & 3 & 5 & 6 & 7 & 9 & 2 & 3 & 4 & 5 & 6 & 7 & 8 & 9 & 12 \\
\hline \multicolumn{17}{|l|}{ ALD-1 } \\
\hline $\mathrm{a}$ & - & - & - & - & - & - & - & - & - & 1.000 & - & - & - & 0.174 & - & - \\
\hline $\mathrm{b}$ & 1.000 & 1.000 & 0.950 & 1.000 & 1.000 & 1.000 & 0.967 & 1.000 & 1.000 & - & 1.000 & 1.000 & 1.000 & 0.826 & 0.900 & 1.000 \\
\hline $\mathrm{c}$ & - & - & 0.050 & - & - & - & 0.033 & - & - & - & - & - & - & - & 1.000 & - \\
\hline \multicolumn{17}{|l|}{ MDH-1 } \\
\hline $\mathrm{a}$ & 0.833 & 1.000 & 0.500 & 0.500 & 1.000 & 0.667 & 0.500 & - & 1.000 & 1.000 & - & - & 1.000 & 0.839 & - & - \\
\hline $\mathrm{b}$ & 0.167 & - & 0.250 & 0.250 & - & - & 0.500 & 1.000 & - & - & 0.500 & 1.000 & - & 0.161 & 0.500 & 1.000 \\
\hline $\mathrm{c}$ & - & - & 0.250 & 0.250 & - & 0.033 & - & - & - & - & 0.500 & - & - & - & 0.500 & - \\
\hline d & - & - & - & - & - & - & - & - & - & - & - & - & - & - & - & - \\
\hline \multicolumn{17}{|l|}{ MDH-2 } \\
\hline a & - & - & - & - & - & - & - & 0.500 & 0.500 & 0.500 & - & 0.500 & 0.500 & 0.500 & - & - \\
\hline $\mathrm{b}$ & 0.500 & 0.500 & 0.500 & 0.500 & 0.500 & 0.500 & 0.500 & 0.500 & 0.500 & 0.500 & 0.500 & 0.500 & 0.500 & 0.500 & 0.500 & 1.000 \\
\hline $\mathrm{c}$ & 0.500 & 0.500 & 0.500 & 0.500 & 0.500 & 0.500 & 0.500 & - & - & - & 0.500 & - & - & - & 0.500 & - \\
\hline d & - & - & - & - & - & - & - & - & - & - & - & - & - & - & - & - \\
\hline \multicolumn{17}{|l|}{ ME-1 } \\
\hline $\mathrm{a}$ & - & - & - & - & - & - & - & - & - & - & - & - & - & 0.167 & - & - \\
\hline b & 1.000 & 1.000 & 1.000 & 1.000 & 1.000 & 0.667 & 1.000 & 1.000 & 0.889 & 1.000 & 1.000 & 1.000 & 1.000 & 0.833 & 1.000 & 1.000 \\
\hline $\mathrm{c}$ & - & - & - & - & - & 0.333 & - & - & 0.111 & - & - & - & - & - & - & - \\
\hline \multicolumn{17}{|l|}{ PGI-1 } \\
\hline $\mathrm{a}$ & - & - & - & - & - & - & - & 1.000 & 1.000 & - & 1.000 & 1.000 & 0.944 & 0.333 & - & 1.000 \\
\hline $\mathrm{b}$ & 1.000 & 1.000 & 1.000 & 1.000 & 1.000 & 1.000 & 1.000 & - & - & 1.000 & - & - & 0.056 & 0.667 & 1.000 & - \\
\hline $\mathrm{c}$ & - & - & - & - & - & - & - & - & - & - & - & - & - & - & - & - \\
\hline \multicolumn{17}{|l|}{ PGI-2 } \\
\hline $\mathrm{a}$ & - & - & 0.250 & 0.250 & - & 0.500 & - & - & 0.500 & - & 0.400 & - & - & - & - & 0.042 \\
\hline $\mathrm{b}$ & 0.833 & 0.500 & 0.500 & 0.500 & 1.000 & 0.500 & 0.500 & 0.500 & - & 0.500 & 0.100 & 0.500 & 0.500 & 0.500 & 1.000 & 0.958 \\
\hline $\mathrm{c}$ & 0.167 & 0.500 & 0.250 & 0.250 & - & - & 0.500 & 0.500 & 0.500 & 0.500 & 0.500 & 0.500 & 0.500 & 0.500 & - & - \\
\hline d & - & - & - & - & - & - & - & - & - & - & - & - & - & - & - & - \\
\hline \multicolumn{17}{|l|}{ PGM-1 } \\
\hline $\mathrm{a}$ & 0.500 & 0.500 & 0.500 & 0.750 & 1.000 & 0.857 & 0.615 & - & 0.500 & 1.000 & 0.500 & - & 0.500 & 0.036 & - & 0.500 \\
\hline $\mathrm{b}$ & 0.500 & 0.500 & 0.500 & 0.250 & - & 0.143 & 0.385 & 0.500 & 0.500 & - & 0.250 & 0.500 & 0.455 & 0.946 & 0.500 & 0.500 \\
\hline $\mathrm{c}$ & - & - & - & - & - & - & - & 0.500 & - & - & 0.250 & 0.500 & 0.045 & 0.018 & 0.500 & - \\
\hline
\end{tabular}




\begin{tabular}{|c|c|c|c|c|c|c|c|c|c|c|c|c|c|c|c|c|c|c|c|}
\hline \multirow{2}{*}{ Locus } & \multicolumn{12}{|c|}{ " KAM } & \multirow{2}{*}{$\begin{array}{c}\text { TAK } \\
1\end{array}$} & \multicolumn{2}{|c|}{ 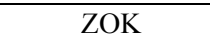 } & \multicolumn{4}{|c|}{ Hybrid population } \\
\hline & 1 & 2 & 4 & 5 & 6 & 8 & 9 & 11 & 14 & 15 & 16 & 17 & & 1 & 2 & 2 & 3 & 4 & 5 \\
\hline \multicolumn{20}{|l|}{ ALD-1 } \\
\hline $\mathrm{a}$ & - & - & - & - & - & 1.000 & - & - & - & 0.500 & - & 0.257 & - & - & - & - & - & - & - \\
\hline $\mathrm{b}$ & 1.000 & 1.000 & 1.000 & 1.000 & 1.000 & - & 1.000 & 1.000 & 1.000 & 0.500 & 1.000 & 0.743 & 1.000 & 1.000 & 0.833 & 1.000 & 1.000 & 1.000 & 1.000 \\
\hline $\mathrm{c}$ & - & - & - & - & - & - & - & - & - & - & - & - & - & - & 0.167 & - & - & - & - \\
\hline \multicolumn{20}{|c|}{ MDH-1 } \\
\hline $\mathrm{a}$ & - & 1.000 & 1.000 & 0.500 & 1.000 & 0.500 & - & 1.000 & - & 1.000 & - & 0.714 & - & - & - & 1.000 & 1.000 & - & 1.000 \\
\hline $\mathrm{b}$ & 1.000 & - & - & - & - & 0.500 & 1.000 & - & 1.000 & - & 1.000 & 0.286 & - & 1.000 & 0.900 & - & - & 1.000 & - \\
\hline $\mathrm{c}$ & - & - & - & 0.250 & - & - & - & - & - & - & - & - & 0.500 & - & 0.100 & - & - & - & - \\
\hline $\mathrm{d}$ & - & - & - & 0.250 & - & - & - & - & - & - & - & - & 0.500 & - & - & - & - & - & - \\
\hline \multicolumn{20}{|c|}{ MDH-2 } \\
\hline $\mathrm{a}$ & - & - & 0.500 & 0.500 & - & 0.500 & 0.500 & - & 0.500 & - & 0.500 & 0.306 & - & 0.500 & 0.500 & - & - & 0.500 & - \\
\hline $\mathrm{b}$ & 0.500 & 0.500 & 0.500 & 0.500 & - & 0.500 & 0.500 & 0.833 & 0.500 & 0.500 & 0.500 & 0.500 & 0.500 & 0.500 & 0.500 & 0.500 & 0.500 & 0.500 & - \\
\hline $\mathrm{c}$ & 0.500 & 0.500 & - & - & 0.500 & - & - & 0.167 & - & 0.500 & - & 0.194 & 0.500 & - & - & 0.500 & 0.500 & - & 0.500 \\
\hline $\mathrm{d}$ & - & - & - & - & 0.500 & - & - & - & - & - & - & - & - & - & - & - & - & - & 0.500 \\
\hline \multicolumn{20}{|l|}{ ME-1 } \\
\hline $\mathrm{a}$ & - & - & - & - & - & - & - & - & - & - & - & - & 1.000 & - & - & - & - & - & - \\
\hline $\mathrm{b}$ & 1.000 & 1.000 & 1.000 & 1.000 & 1.000 & 1.000 & 1.000 & 1.000 & 1.000 & - & 1.000 & 1.000 & - & 0.500 & 0.119 & 1.000 & 1.000 & 1.000 & 1.000 \\
\hline $\mathrm{c}$ & - & - & - & - & - & - & - & - & - & 1.000 & - & - & - & 0.500 & 0.881 & - & - & - & - \\
\hline \multicolumn{20}{|l|}{ PGI-1 } \\
\hline $\mathrm{a}$ & 1.000 & - & 1.000 & 0.950 & - & - & 1.000 & - & - & 1.000 & - & - & - & - & 0.548 & - & - & 1.000 & 1.000 \\
\hline $\mathrm{b}$ & - & 1.000 & - & 0.050 & 1.000 & 1.000 & - & 1.000 & 1.000 & - & 1.000 & 1.000 & 1.000 & 1.000 & 0.452 & 0.500 & 0.500 & - & - \\
\hline $\mathrm{c}$ & - & - & - & - & - & - & - & - & - & - & - & - & - & - & - & 0.500 & 0.500 & - & - \\
\hline \multicolumn{20}{|l|}{ PGI-2 } \\
\hline $\mathrm{a}$ & 0.500 & 0.500 & - & 0.500 & 0.500 & 0.500 & 0.500 & - & 0.167 & - & 0.500 & 0.500 & - & 0.028 & 0.032 & - & - & - & - \\
\hline $\mathrm{b}$ & 0.500 & 0.500 & 1.000 & 0.500 & - & 0.500 & 0.500 & - & 0.833 & 0.500 & 0.500 & 0.500 & - & 0.417 & 0.177 & 0.500 & 0.500 & 0.500 & 0.500 \\
\hline $\mathrm{c}$ & - & - & - & - & 0.500 & - & - & 1.000 & - & 0.500 & - & - & 0.500 & 0.556 & 0.710 & 0.500 & 0.500 & 0.500 & 0.500 \\
\hline $\mathrm{d}$ & - & - & - & - & - & - & - & - & - & - & - & - & 0.500 & - & 0.081 & - & - & - & - \\
\hline \multicolumn{20}{|l|}{ PGM-1 } \\
\hline $\mathrm{a}$ & 0.500 & 0.500 & 0.500 & 0.250 & - & 1.000 & 0.500 & - & - & - & 0.500 & 0.500 & 0.500 & - & 0.120 & 0.500 & 0.500 & - & 0.500 \\
\hline
\end{tabular}

LAT, S. latiovalifolium; AIZ, S. aizoon; KAM, S. kamtschaticum; TAK, S. takesimense; ZOK, S. zokuriense. 
Table 5. Level of genetic variation for 7 isozyme loci within 35 populations Sedum latiovalifolium and related species.

\begin{tabular}{|c|c|c|c|c|c|}
\hline \multirow{2}{*}{ Populations } & \multirow{2}{*}{ M } & \multirow{2}{*}{$A$} & \multirow{2}{*}{$P$} & \multicolumn{2}{|c|}{ Mean heterozygosity } \\
\hline & & & & $H_{\mathrm{o}}$ & $H_{\mathrm{e}}$ \\
\hline \multicolumn{6}{|l|}{$\overline{\text { S. latiovalifolium }}$} \\
\hline LAT1 & 14.0 & 1.6 & 57.1 & 0.381 & 0.231 \\
\hline LAT2 & 14.3 & 1.4 & 42.9 & 0.429 & 0.222 \\
\hline LAT3 & 18.6 & 2.0 & 71.4 & 0.500 & 0.346 \\
\hline LAT5 & 10.0 & 1.9 & 57.1 & 0.429 & 0.320 \\
\hline LAT6 & 5.0 & 1.1 & 14.3 & 0.143 & 0.0479 \\
\hline LAT7 & 12.0 & 1.7 & 71.4 & 0.327 & 0.317 \\
\hline LAT9 & 11.9 & 1.7 & 57.1 & 0.548 & 0.305 \\
\hline Mean & 12.3 & 1.6 & 53.0 & 0.394 & 0.26 \\
\hline \multicolumn{6}{|l|}{ S. aizoon } \\
\hline AIZ2 & 3.6 & 1.4 & 42.9 & 0.429 & 0.306 \\
\hline AIZ3 & 9.0 & 1.6 & 57.1 & 0.429 & 0.257 \\
\hline AIZ4 & 6.1 & 1.3 & 28.6 & 0.286 & 0.220 \\
\hline AIZ5 & 13.1 & 1.9 & 57.1 & 0.571 & 0.331 \\
\hline AIZ6 & 4.7 & 1.4 & 42.9 & 0.429 & 0.244 \\
\hline AIZ7 & 9.3 & 1.7 & 57.1 & 0.444 & 0.248 \\
\hline AIZ8 & 28.7 & 2.1 & 100.0 & 0.444 & 0.346 \\
\hline AIZ10 & 10.0 & 1.6 & 57.1 & 0.429 & 0.253 \\
\hline AIZ12 & 12.0 & 1.3 & 14.3 & 0.155 & 0.086 \\
\hline Mean & 10.7 & 1.5 & 50.8 & 0.402 & 0.255 \\
\hline \multicolumn{6}{|l|}{ S. kamtschaticum } \\
\hline KAM1 & 3.6 & 1.4 & 42.9 & 0.429 & 0.306 \\
\hline KAM2 & 8.7 & 1.4 & 42.9 & 0.429 & 0.293 \\
\hline KAM4 & 6.0 & 1.3 & 28.6 & 0.286 & 0.156 \\
\hline KAM5 & 8.7 & 2.0 & 71.4 & 0.514 & 0.420 \\
\hline KAM6 & 7.0 & 1.3 & 28.6 & 0.286 & 0.154 \\
\hline KAM8 & 5.3 & 1.4 & 42.9 & 0.429 & 0.299 \\
\hline KAM9 & 5.4 & 1.4 & 42.9 & 0.429 & 0.297 \\
\hline KAM11 & 10.7 & 1.1 & 14.3 & 0.048 & 0.041 \\
\hline KAM14 & 15.7 & 1.4 & 42.9 & 0.262 & 0.169 \\
\hline KAM15 & 9.9 & 1.6 & 57.1 & 0.571 & 0.301 \\
\hline KAM16 & 10.0 & 1.4 & 42.9 & 0.429 & 0.226 \\
\hline KAM17 & 19.4 & 1.9 & 71.4 & 0.429 & 0.422 \\
\hline Mean & 9.2 & 1.5 & 42.6 & 0.378 & 0.257 \\
\hline \multicolumn{6}{|l|}{ S. takesimense } \\
\hline TAK1 & 5.0 & 1.6 & 57.1 & 0.571 & 0.317 \\
\hline \multicolumn{6}{|l|}{ S. zokuriense } \\
\hline ZOK1 & 18.0 & 1.7 & 57.1 & 0.294 & 0.296 \\
\hline $\mathrm{ZOK} 2$ & 24.7 & 2.4 & 100.0 & 0.479 & 0.395 \\
\hline Mean & 21.35 & 2.1 & 78.6 & 0.387 & 0.346 \\
\hline \multicolumn{6}{|l|}{ Hybrid population } \\
\hline HYB2 & 8.1 & 1.6 & 57.1 & 0.571 & 0.368 \\
\hline HYB3 & 3.7 & 1.6 & 57.1 & 0.571 & 0.387 \\
\hline HYB4 & 1.9 & 1.3 & 28.6 & 0.286 & 0.190 \\
\hline HYB5 & 3.6 & 1.4 & 42.9 & 0.429 & 0.306 \\
\hline
\end{tabular}

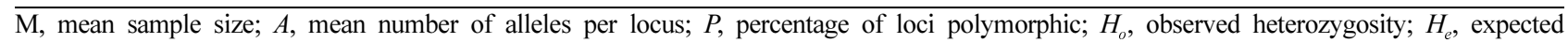
heterozygosity; LAT, S. latiovalifolium; AIZ, S. aizoon; KAM, S. kamtschaticum; TAK, S. takesimense; ZOK, S. zokuriense; HYB, hybrid population. 
Table 6. Deviation from Hardy-Weinberg equilibrium among individuals $\left(F_{\mathrm{IS}}\right)$, among populations $\left(F_{\mathrm{IT}}\right)$ and total deviation $\left(F_{\mathrm{ST}}\right)$ for 7 loci from Sedum latiovalifolium related species.

\begin{tabular}{|c|c|c|c|c|c|c|c|c|c|c|c|c|}
\hline \multirow{2}{*}{ Locus } & \multicolumn{3}{|c|}{ "LAT } & \multicolumn{3}{|c|}{ 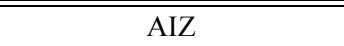 } & \multicolumn{3}{|c|}{ KAM } & \multicolumn{3}{|c|}{ ZOK } \\
\hline & $F_{\text {IS }}$ & $F_{\text {IT }}$ & $F_{\mathrm{ST}}$ & $F_{\text {IS }}$ & $F_{\text {IT }}$ & $F_{\mathrm{ST}}$ & $F_{\text {IS }}$ & $F_{\text {IT }}$ & $F_{\mathrm{ST}}$ & $F_{\text {IS }}$ & $F_{\text {IT }}$ & $F_{\mathrm{ST}}$ \\
\hline MDH-1 & 0.056 & 0.299 & 0.257 & -0.828 & 0.546 & 0.762 & 0.222 & 0.763 & 0.758 & 0.111 & 0.053 & 0.053 \\
\hline MDH-2 & -1.000 & -0.670 & 0.165 & -1.000 & -0.565 & 0.217 & 0.922 & 0.459 & 0.241 & 1.000 & 1.000 & 0.000 \\
\hline PGM-1 & -0.756 & -0.573 & 0.138 & -0.886 & -0.248 & 0.338 & 0.889 & 0.285 & 0.320 & 0.833 & 0.809 & 0.013 \\
\hline ME-1 & 1.000 & 1.000 & 0.308 & 0.299 & 0.386 & 0.124 & - & 1.000 & 1.000 & 0.665 & 0.721 & 0.170 \\
\hline ALD-1 & 0.582 & 0.596 & 0.034 & 0.256 & 0.843 & 0.789 & 0.134 & 0.667 & 0.706 & 0.200 & 0.091 & 0.091 \\
\hline PGI-1 & - & - & - & 0.798 & 0.971 & 0.855 & 0.053 & 0.983 & 0.984 & 0.870 & 0.919 & 0.378 \\
\hline PGI-2 & -0.761 & -0.412 & 0.199 & -0.935 & -0.354 & 0.300 & 0.953 & 0.264 & 0.353 & 0.413 & 0.438 & 0.043 \\
\hline Mean & -0.581 & -0.350 & 0.146 & -0.783 & 0.094 & 0.492 & 0.796 & 0.180 & 0.544 & 0.144 & 0.026 & 0.103 \\
\hline
\end{tabular}

LAT, S. latiovalifolium; AIZ, S. aizoon; KAM, S. kamtschaticum; ZOK, S. zokuriense.

아주 유사한 유전적 조성과 유전적 동일성을 보여주었으 며 $(0.909,0.921)$, 또한 전형질도에서도 태백기린초와 기린 초 사이에 유집되어 두 집단이 태백기린초와 기린초의 교 잡에 의해 만들어 졌을 가능성을 시사했다. 가는기린초와 태백기린초의 교잡 집단으로 추정되었던 HYB4는 가는기 린초에 유집되었고, 가는기린초와 기린초의 교잡 집단으 로 추정되었던 HYB5는 가는기린초, 기린초와 함께 유집 되었다(Fig. 5).

\section{고 찰}

\section{태백기린초의 교잡 기원}

식물에 있어 교잡에 의한 종분화는 크게 이배체 수준의 교잡과 다배체 수준의 종분화로 대변할 수 있는데, 특히 자연집단 내 교잡 기원에 관한 검증은 식물의 종분화 과 정을 이해하는 데 매우 중요하다(Mahy et al., 2000). 최근 교잡 기원에 대한 주요 연구를 보면 Morrell and Rieseberg (1998)는 형태형질과 동위효소, DNA분석을 통해 꽃고비 과 내 Gilia achilieifolia가 교잡종이 아니라 독립적인 역사 를 가지고 있음을 밝혀냈고, Rieseberg et al. (1990)은 국화 과 Helianthus종이 이배체 교잡에 의해 기원되었음을 밝혀 낸바있다. Sun (1996)은 염색체 분석과 동위효소분석을 통 해 난초과 Spinranthes hongkongensis종이 S. sinensis와 $S$. spiralis의 교잡종임을 검증하였다. Gastony(1986)은 Asplenium 복합체에 대한 교잡 기원을 동위효소 분석을 통 해 밝혀내었다.

국내 교잡종에 관한 연구는 Park et al. (2003)이 이배체 지리고들빼기(P. koidzumiana)가 교잡 기원 종이 아님을 동 위효소 분석을 통해 검증하였고, Lee et al. (2001)은 Lycoris flavescens 가 타가삼배체로 L. chinensis와 L. sanguinea var. koreana 사이에서 교잡을 통해 기원되었다는 것을 입증한 바 있다. 이와 같이 일부 한국 고유종에 대한 동위효소 분 석은 교잡의 기원을 밝히는 데 유용하게 사용되어 왔다.
Lee (1992)에 의해 신종 기재된 태백기린초는 Lee (2000) 가 금대기린초란 국명으로 신칭하며 가는기린초와 기 린초나 가는기린초와 넓은잎기린초 사이의 교잡종일 가능성을 제기하였는데, 본 연구는 이를 규명하기 위해 형태형질과 동위효소 분석을 하였다. 형태형질을 기초 로 한 수리분석 결과, 한국특산 태백기린초는 독립된 유집과 공간상의 배열을 보여주어 형태적으로 뚜렷이 구분되는 독립된 종으로 여겨지며 이와 같은 결과는 Lee (2000)의 가는기린초와 기린초나 기린초와 넓은잎 기린초의 교잡종일 가능성을 지지하지 않는다. 동위효 소를 이용한 본 연구 결과를 살펴보아도 태백기린초에 서는 나타나지 않는 $\mathrm{MDH}-2^{\mathrm{a}}$ 는 가는기린초와 기린초, 속리기린초에는 높은 빈도로 나타났고, PGI-1 ${ }^{\mathrm{a}}$ 또한 태 백기린초에는 나타나지 않았지만 가는기린초, 기린초, 속리기린초에는 나타나고 있어, 모종으로 추정되었던 가는기린초, 기린초에 나타나는 대립인자가 태백기린 초에는 전혀 나타나지 않아 교잡 기원 가능성을 역시 지지할 수 없었다. 또한 일반적으로 피자식물에 있어 유전적 동일성이 0.9 이상(Crawford, 1983)인 것을 고려 할 때 태백기린초와 기린초(0.724), 가는기린초(0.689) 종간의 유전적 동일성이 상대적으로 낮게 나타나 이들 종들이 독립적으로 분화한 지 오래되었을 가능성이 크 다. 따라서 이들 종간의 교잡을 통해 태배기린초가 기 원되었을 가능성은 매우 희박하다고 생각된다. 하지만 유전적 동질성을 이용한 전형질도를 보면 기린초의 일 부 집단이 태백기린초 집단 안에 유집되는 것으로 나타 났고, 형태형질에 의한 전형질도에서 태백기린초와 기 린초, 가는기린초의 일부 집단이 서로 섞이어 유집되는 것으로 나타나고 있어 태백기린초가 교잡의 기원을 가 진 종이기보다는 기린초와 가는기린초와는 독립적으 로 분화된 종이지만 최근에 이들 일부 집단 간에 형질 이입(introgression)등과 같은 유전적 교류가 있었음을 보 여주는 증거라 하겠다. 


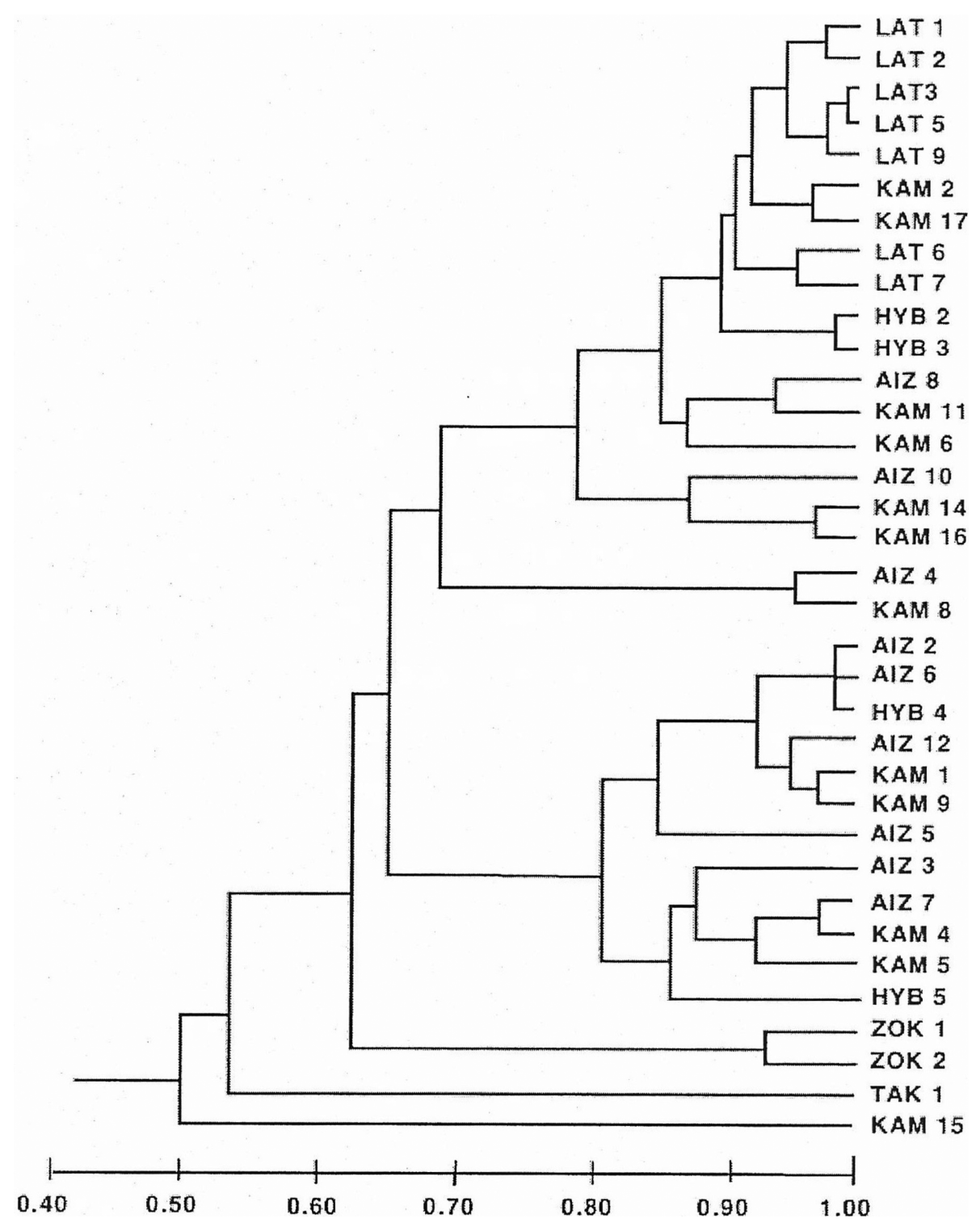

Fig. 5. Unweighted pair-group method using arithmetic average phenogram based on the Nei's (1972) genetic identity for 35 populations of Sedum latiovalifolium and related species. AIZ, S. aizoon; HYB, hybrid population; KAM, S. kamtschaticum; LAT, S. latiovalifolium; TAK, S. takesimense; ZOK, S. zokuriense.

\section{가는 기린초아속내 종간 유전적 교류}

가는기린초와 태백기린초의 교잡 집단으로 추정되는 $\mathrm{HYB} 1$ 은 가는기린초 집단(AIZ7, 11, 9)들과 유집이 되었 으며, 주요인분석 결과 가는기린초와 가까운 공간상 배 열하여 본 집단은 아마도 태백기린초에서 가는기린초 집 단으로 형질이입이 되었거나 가는기린초 집단일 가능성 이 큰 것으로 생각된다. 기린초와 태백기린초의 교잡 집 단으로 추정되는 HYB2, HYB3집단은 태백기린초와 아 주 유사한 유전적 조성을 가지고 있었고, 태백기린초와 유전적 동일성 또한 매우 높게 나타났다 $(0.909,0.921)$. 특 히, 전형질도에서도 태백기린초와 기린초 사이에 유집되 는 것으로 보아 두 집단은 기린초가 태백기린초 집단 쪽
으로 형질이입에 의한 유전적 교류 결과 만들어진 집단 으로 추정된다. 가는기린초와 태백기린초의 교잡 집단으 로 추정되었던 $\mathrm{HYB} 4$ 은 가는기린초 집단들과 유집되어 고, 가는기린초와 기린초의 교잡으로 추정되었던 HYB5 은 가는기린초, 기린초와 함께 유집되었으며 대립유전자 빈도에 있어서도 PGM-1에서 기린초와 유사하고, PGI-2 는 가는기린초와 유사한 것으로 보아 가는기린초와 기린 초사이의 교잡 집단일 가능성이 매우 크다고 하겠다. 이 렇듯 본 연구결과 가는기린초와 기린초 집단 간에 유전 적 교류가 빈번하게 일어나고 있음을 시사하고 있어 이 를 명확히 검증하기 위해 다양한 분자마커를 이용한 분 석이 요구된다고 하겠다. 


\section{돌나물속 가는기린초아속 식물들의 종간 유연 관계}

형태형질에 의한 수리분석의 결과 태백기린초, 섬기린 초, 애기기린초, 속리기린초는 각각의 독립된 유집과 공 간상의 배열을 하고 있는 반면, 가는기린초는 금대봉일대 에서 채집한 집단들과 그의 지역에 채집한 집단들이 떨 어져서 유집되는 결과를 나타내고 있어 이들 집단군간에 서로 다른 진화적 역사가 있었음을 시사한다. 기린초집 단들 또한 두 개의 유집을 형성하는 것으로 나타났다. 동 위효소 분석의 결과에서도 태백기린초, 섬기린초, 애기 기린초, 속리기린초는 독립된 유집을 형성하지만 가는기 린초, 기린초는 서로 섞이어 유집되는 것으로 나타나 이들 종간에 빈번한 유전적 교류가 있음을 시사한다. 하지만 종 간의 유전적 동일성이 낮게 나타나는 것으로 보아 두 종의 분화가 오래되었음을 보여주고 있어 최근 두 종간에 지역 적으로 유전적 교류가 있을 수 있음을 나타낸다.

돌나물과 가는기린초아속 식물 중 섬기린초, 속리기린 초는 일부 지역에 국지적으로 분포하는 종으로 알려져 있 고, 기린초, 가는기린초, 종들은 넓게 분포하는 종으로 알 려져 있다(Oh, 1985; Chung and Kim, 1989). 각 분류군에 대 한 유전적 변이를 보면 좁게 분포하는 섬기린초와 속리기 린초가 기린초, 가는기린초에 비해 높은 유전적 변이를 보여주었는데, 이는 이배체종인 섬기린초, 속리기린초는 유성생식과 타가수분을 주로 하는 종으로 높은 유전적 다 양성을 유지하는 반면, 기린초와 가는기린초는 다배체나 이수체로 무성생식을 주로 하는 종으로 유전적 변이가 상 대적으로 낮을 가능성이 있다고 추정된다.

결론적으로 태백기린초는 교잡에 의해 생긴 종이 아니 라 독립적으로 분화되었으며 최근에 기린초, 가는기린초 와 유전적 교류가 빈번한 종으로 생각된다. Uhl and Moran (1972)와 Soeda (1944), Amano (1990)의 염색체 연구에서 밝혀졌듯이 가는기린초아속 식물들은 종 내 염색체 수와 형태형질의 변이가 심한 분류군으로, Chung and Kim (1989) 또한 기린초의 변이의 다양성에 대해 지적한 바가 있어 이들 간에 유전적 교류나 교잡이 형태적 변이와 종 의 한계를 불분명하게 했을 가능성이 높다고 생각된다.

\section{Acknowledgments}

The authors thank two anonymous reviewers for their constructive comments.

\section{Literature Cited}

Amano, M. 1990. Biosystematic study of Sedum L. subgenus Aizoon (Crassulaceae). I. Cytological and morphological variations of Sedum aizoon L. var. floribundum Nakai. Botanical Magazine Tokyo 103: 67-85.

Amano, M. and H. Ohba. 1992. Chromosome number of Sedum sikokianum Maxim. (Crassulaecease). Journal of Japanese Botany 65: 167-170.

Arnold, M. L. and S. A. Hodges. 1995. Are natural hybrids fit or unfit relative to their parents? Trends in Ecology and Evolution 10: 67-71.

Chung, T. H. 1957. Korean Flora. Singisa, Seoul. Pp. 281-291.

Chung, Y. H. and J. H. Kim. 1989. A taxonomic study of Sedum section Aizoon in Korea. Korean Journal of Plant Taxonomy 19: 189-227.

Crawford, D. J. 1983. Phylogenetic and systematic inferences from electrophoretic studies. In Isozymes in Plant Genetics and Breeding. Tanksley, S. D. and T. J. Orton (eds.), Elsevier, Amsterdam. Pp. 257-287.

Crawford, D. J. 1989. Enzyme electrophoresis and plant systematics. In Isozymes in Plant Biology. Soltis, D. E. and P. S. Soltis (eds.), Discorides Press, Portland. Pp. 146-164.

Ellstrand, N. C., R. Whitkus and L. H. Rieseberg. 1996. Distribution of spontaneous plant hybrids. Proceedings of the National Academy of Sciences of the United States of America 93: 5090-5093.

Gallez, G. P. and L. D. Gottlieb. 1982. Genetic evidence for the hybrid origin of the diploid plant Stephanomeria diegensis. Evolution 36: 1158-1167.

Gastony, G. J. 1986. Electrophoretic evidence for the origin of fern species by unreduced spores. American Journal of Botany 73: $1563-1569$.

Gottlieb, L. D. 1981. Eletrophoretic evidence and plant populations. In Progress in Phytochemistry, Vol. 7. Reinhold, L., J. B. Harborne and T. Swain (eds.), Pergamon Press, New York. Pp. $1-46$.

Lee, N.-S., M. Kim, B.-S. Lee and K.-R. Park. 2001. Isozyme evidence for the allotriploid origin of Lycoris flavescens (Amaryllidaceae). Plant Systematics and Evolution 227: 227-234.

Lee, T. B. 2000. A natural hybrid of the genus Sedum. Natural Plant 50: 5-6.

Lee, Y. N. 1992. New taxa on Korean flora (4). Korean Journal of Plant Taxonomy 22: 7-11.

Lee, Y. N. 1996. Flora of Korea. Kyo-Hak Publishing, Seoul. Pp. 268-278.

Mahy, G., L. P. Bruederle, B. Connors, M. Van Hofwegen and N. Vorsa. 2000. Allozyme evidence for genetic autopolyploidy and high genetic diversity in tetraploid cranberry, Vaccinium oxycoc$\cos$ (Ericaceae). American Journal of Botany 87: 1882-1889.

Morrell, P. and L. Rieseberg. 1998. Molecular tests of the proposed diploid hybrid origin of Gilia achilleifolia (Polemoniaceae). American Journal of Botany 85: 1439-1453.

Nakai, T. 1909. Flora Koreana II. Journal of the College of Science, Imperial University of Tokyo 26: 226-231. 
Nei, I. 1972. Genetic distance between populations. American Naturalist 106: 283-292.

Oh, S. 1985. The phytogeographical studies of family Crassulaceae in Korea. Research Review Kyungpook National University 39: $123-159$.

Park, K.-R., J.-H. Pak and B.-B. Seo. 2003. Allozyme variation in Paraixeris: a test for the diploid hybrid origin of Paraixeris koidzumiana (Compositae). Botanical Bulletin of Academia Sinica 44: 113-122.

Park, M. K. 1974. Keys to the Herbaceous Plants in Korea (Dicotyledoneae). Chungunsa, Seoul. Pp. 151-158.

Rieseberg, L. H., R. Carter and S. Zona. 1990. Molecular tests of the hypothesized hybrid origin of two diploid Helianthus species (Asteraceae). Evolution 44: 1489-1511.

Rieseberg, L. H., N. C. Ellstrand and M. Arnold. 1993. What can molecular and morphological makers tell us about plant hybridization? Critical Review of Plant Science 12: 213-241.

Rieseberg, L. H. and J. F. Wendel. 1993. Introgression and its consequences in plants. In Hybrid Zones and the Evolutionary Process. Harrison R. G. (ed.), Oxford University Press, New York. Pp. 70-109.

Rohlf, F. J. 1992. NTSTS-pc: Numerical Taxonomy and Multivar- iate Analysis System (version 1.70) [Computer program]. Exeter Software, New York.

Soeda, T. 1944. A cytological study on the genus Sedum, with remarks on the chromosome numbers of some related plants. Journal of the Faculty of Science of the Hokkaido Imperial University Series 5, Botany 5: 221-231.

Soltis, D. E., C. H. Haufler, D. C. Darrow and G. J. Gastony. 1983. Starch gel electrophoresis of ferns: a compilation of grinding buffers, gel and electrode buffers, and staining schedules. American Fern Journal 73: 9-27.

Sun, M. 1996. The allopolyploid origin of Spiranthes hongkongensis (Orchidaceae). American Journal of Botany 83: 252260.

Swofford, D. L. and R. B. Selander. 1981. BIOSYS-1: a FORTRAN program for the comprehensive analysis of electrophoretic data in population genetics and systematics. Journal of Heredity 72: 281-283.

Uhl, C. H. and R. Moran. 1972. Chromosomes of Crassulaceae from Japan and South Korea. Cytologia 37: 59-81.

Wright, S. 1978. Evolution and the Genetics of Population, Vol. 4. Variability within and among Natural Population. University of Chicago Press, Chicago, IL, 590 pp. 